\title{
Pengembangan Buku Panduan Membaca Cerita Sebagai Bahan Ajar Tambahan Memahami Cerita Untuk Siswa Kelas IV Sekolah Dasar
}

\author{
Elma Asfiatuz Zahro,1, Maria Ulfa Yuda, S.Pd., M.A ${ }^{2}$, Sripit Widiastuti, S.Pd., M.Pd. ${ }^{3}$ \\ ${ }^{123}$ UNISBA, Jalan Majapahit No.2-4 Kec.Sananwetan, (0342) 813145 \\ Program Studi Pendidikan Guru Sekolah Dasar, FKIP Universitas Islam Balitar, Blitar \\ e-mail: *1 elmaasfiatuz@gmail.com, ${ }^{2}$ mariaulfayuda90@ gmail.com, ${ }^{3}$ sripitpgsd@gmail.com
}

\begin{abstract}
Abstrak
Tujuan pengembangan bahan ajar dalam penelitian ini adalah untuk menghasilkan bahan ajar yang dapat meningkatkan pemahaman siswa terhadap isi cerita yang dibaca dengan panduan sebelum membaca cerita untuk siswa kelas IV SD. Panduan membaca cerita yang digunakan dikaitkan dengan materi unsur intrinsik cerita yang dipaparkan secara bertahap. Penelitian ini menggunakan jenis penelitian dan pengembangan dari model Borg and Gall yang telah diadopsi dan dikembangkan oleh Sugiyono. Adapun tahapan penelitian dan pengembangan hanya dibatasi 7 tahapan penelitian. Ketujuh tahapan tersebut adalah mencari potensi dan masalah, melakukan penelitian dan pengumpulan data, desain produk, validasi desain, revisi desain, melakukan uji coba produk, dan revisi produk. Validasi buku pancarita ini dilakukan oleh validator materi, bahasa, dan media. Hasil validasi buku PANCARITA menunjukkan bahwa (1) validasi ahli media diperoleh persentase $90 \%$ dan termasuk kategori sangat layak, (2) validasi ahli materi $85 \%$ termasuk kategori layak, (3) validasi ahli bahasa $88 \%$ termasuk kategori layak. Hasil uji keterbacaan siswa menunjukkan kategori sangat layak dengan persentase $95 \%$. Hasil uji keterbacaan guru menunjukkan kategori sangat layak dengan persentase $93 \%$.
\end{abstract}

Kata kunci: buku panduan, membaca, pengembangan

\section{The Development Of A Reading Guide As Additional Teaching Material Understanding Stories For Class IV Elementary Schools}

\begin{abstract}
The purpose of this study was to develop teaching materials that can improve the fourth-grade students' understanding of the content of stories read with a guide before reading the stories. The guide to reading the stories is related to the intrinsic elements of the stories which are presented in stages. This study applied Borg and Gall's research and development model that has been adopted and developed by Sugiyono. The research and development stages applied in this study only consisted of 7 stages. The seven stages included seeking potentials and problems,conducting research and collecting data, designing the product,validating the design, revising the design, testing the product, and revising the product. The validation of the PANCARITA book was carried out by the experts of material, language, and media. The results of the validation revealed that (1) the feasibility of the media obtained a percentage of $90 \%$, and it is classified intothe very feasible category; (2) the feasibility of the material earned a percentage of $85 \%$ which belongs to the feasible category; and (3) the feasibility ofthe language gained a percentage of $88 \%$, which is categorized into the feasible category. The student readability test obtained a percentage of $95 \%$ indicating that the book is very feasible. Similarly, the teacher readability test gained a percentage of $93 \%$ denoting that the book is very feasible.
\end{abstract}

Keywords: development, guide book, reading

\section{PENDAhUluAN}

Pengembangan bahan ajar merupakan suatu hal yang sangat penting untuk penyampaian pembelajaran di sekolah. Pengembangan bahan ajar dikatakan sangat penting karena, dalam suatu pengembangan pasti akan menciptakan sesuatu yang lebih menarik dan memiliki kreatifitas yang tinggi sesuai dengan kebutuhan guru atau siswa. Pengembangan bahan ajar tersebut bertujuan agar siswa tidak merasa bosan selama proses pembelajaran. Selain itu, agar siswa lebih antusias dan bersemangat dalam memahami materi yang disampaikan oleh guru 
terutama dalam memahami cerita yang dibaca. Pengertian bahan ajar itu sendiri merupakan segala bahan baik informasi, alat, maupun teks yang disusun secara sistematis yang menampilkan sosok utuh dari kompetensi yang akan dikuasai siswa dan digunakan dalam proses pembelajaran dengan tujuan untuk perencanaan dan penelaah implementasi pembelajaran [1].

Berdasarkan hasil observasi, selama proses pembelajaran banyak siswa berpendapat bahwa bahan ajar yang digunakan kurang menarik dan terlalu banyak bacaan yang dipaparkan terutama pada teks cerita. Mereka merasa kesulitan memahami isi cerita karena kurangnya bahan ajar yang sesuai dengan keinginan mereka seperti buku cerita bergambar, buku cerita yang bacaannya tidak terlalu panjang, dan buku yang memiliki warna bervariasi disertai gambar ilustrasi ceritanya. Selain itu, siswa merasa bahwa selama kegiatan membaca berlangsung, guru kurang memberikan bimbingan yang baik dan guru juga membatasi waktu mereka untuk membaca. Sedangkan tujuan umum membaca itu sendiri adalah untuk memperoleh informasi faktual, memperoleh pengetahuan yang luas, dan agar bisa memahami isi suatu bacaan yang dibaca [2]. Sedangkan dilihat dari beberapa hasil analisis kebutuhan siswa di beberapa sekolah dasar menunjukkan bahwa $20 \%$ siswa sudah bisa memahami isi cerita dan 41\% dari 64 siswa belum bisa memahami isi cerita dengan baik. Hal itu disebabkan karena, siswa kurang berkonsentrasi dalam membaca cerita. Siswa kurang berkonsentrasi dalam membaca cerita karena beberapa hal diantaranya yaitu, 20\% siswa ramai sendiri ketika kegiatan membaca dan 19\% siswa tidak suka membaca cerita. Oleh karena itu, diperlukan pengembangan bahan ajar yang dapat membantu siswa dalam memahami isi dari cerita yang dibaca dan pengembangan bahan ajar yang dapat mengarahkan guru untuk membimbing siswa selama kegiatan membaca. Bahan ajar yang dimaksud tersebut adalah bahan ajar buku panduan membaca cerita (PANCARITA) yang difokuskan untuk siswa kelas IV SD yang panduan membacanya dikaitkan dengan materi unsur intrinsik cerita. Buku PANCARITA ini di bagi menjadi dua buku yaitu, buku siswa dan buku guru. Selain itu, buku ini dilengkapi dengan materi unsur intrinsik cerita, panduan membaca guru, panduan membaca siswa, cerita anak, dan soal pemahaman. Buku PANCARITA berisikan 4 cerita dengan judul cerita yang berbeda disertai ilustrasi gambar menarik yang disesuaikan dengan isi ceritanya.

Berdasarkan pemaparan masalah di atas dapat diperoleh solusi dilihat dari penelitian terdahulu oleh Machmuda (2013) dengan judul Pengembangan Bahan Ajar Membaca Cerita Anak Berbasis Cerita Rakyat Jawa Timur Untuk Siswa Kelas V MI Nurul Huda Malang, dilengkapi materi unsur cerita, cerita rakyat Jawa Timur, dan soal latihan. Bahan ajar ini dinyatakan layak dan valid dengan presentase kevalidan menurut ahli materi 88,5\%,ahli media 80\%, ahli pembelajaran 83,7\%, dan siswa kelas V 91,5\% [3]. Kristianto (2017) dengan judul Pengembangan Buku Cerita Anak Berbasis Pendidikan Lingkungan Hidup untuk Pembelajaran Membaca Kelas Bawah,dilengkapi dengan refleksi di bagian akhir bahan ajar yang dikembangkan.Bahan ajar ini dinyatakan layak dan valid dengan jumlah perhitungan skor yang diperoleh adalah 3,82\% dengan kategori "Baik" [4].

Dilihat dari kedua penelitian terdahulu tersebut masih ditemukan beberapa kekurangan diantaranya adalah belum adanya soal pemahaman, panduan membaca cerita, dan pemaparan materi secara bertahap. Oleh karena itu, peneliti melakukan penelitian pengembangan dengan judulPengembangan Buku Panduan Membaca Cerita (PANCARITA) untuk Siswa Kelas IV SD.

\section{METODE PENELITIAN}

Jenis penelitian yang digunakan adalah jenis Research and Development (R\&D) yaitu metode penelitian yang digunakan untuk menghasilkan produk tertentu dengan menguji keefektifan produk tersebut [5]. Pengembangan bahan ajar ini memakai 7 tahap penelitian dan pengembangan dari model Borg and Gall yang telah diadopsi dan dikembangkan oleh Sugiyono yang bentuk langkah-langkahnya yaitu, mencari potensi dan masalah, melakukan penelitian dan pengumpulan data, desain produk, validasi desain, revisi desain, melakukan uji coba produk, dan revisi produk. Adapun kerangka kerjanya seperti tampak pada Gambar 1

Uji coba pada penelitian ini dilakukan secara terbatas terhadap 10 siswa kelas V SD dan 5 guru kelas IV. Sedangkan teknik pengumpulan data pada penelitian ini menggunakan angket validasi untuk ahli media, ahli materi, dan ahli bahasa. Selain angket validasi, penelitian ini juga menggunakan angket uji keterbacaan untuk siswa dan guru yang digunakan selama uji coba keterbacaan buku PANCARITA. Analisis data yang digunakan dalam penelitian ini adalah analisis data kualitatif dan data kuantitatif. Data yang dianalisis secara kualitatif yaitu data yang diperoleh dari angket terbuka pada angket validasi ahli, angket keterbacaan guru dan angket keterbacaan siswa. Sedangkan data yang dianalisis secara kuantitatif adalah data yang diperoleh dari hasil angket validasi ahli, angket keterbacaan siswa dan guru. Data tersebut berisi penilaian yang akan dihitung dengan teknik perhitungan nilai persentase yang akan dianalisa menggunakan analisa deskriptif. Proses penilaian angket keterbacaan dan kelayakan bahan ajar di peroleh dari rumus dan ketentuan pada persamaan 1. 


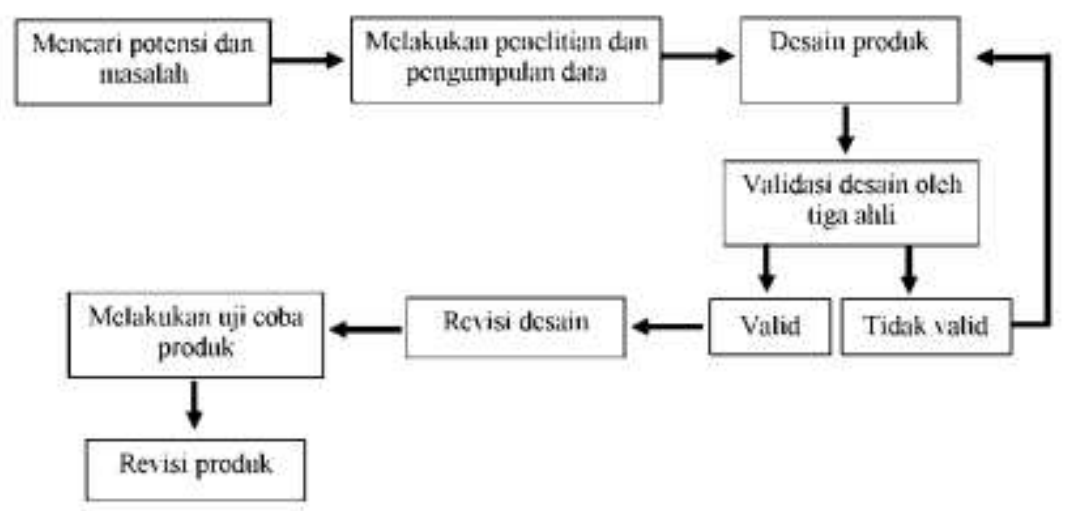

Gambar 1 Kerangka Kerja Penelitian dan Pengembangan

$$
\begin{aligned}
\mathrm{P} & =\frac{\sum x}{\sum x t} x 100 \% \\
\mathrm{P} & =\text { Kelayakan } \\
\sum x \quad & =\text { Jumlah jawaban pilihan } \\
\sum x t & =\text { Jumlah jawaban tertinggi }
\end{aligned}
$$

Setelah menghitung penilaian validasi dan kelayakan diatas, selanjutnya ada rumus untuk menentukan hasil uji keterbacaan siswa dan guru terhadap buku panduan sebagai berikut.

$$
\text { Persentase }=\frac{\text { jumlahtotalnilai }}{\text { nilaimaksimal }} \times 100 \%
$$

Setelah diketahui persentase dari hasil penilaian validasi dan keterbacaan yang dilakukan maka langkah selanjutnya adalah membandingkan persentase yang diperoleh dengan kriteria kelayakan atau kevalidan bahan ajar. Kriteria tersebut adalah seperti pada Tabel 1. [6].

Tabel 1 Kriteria Kelayakan Bahan Ajar

\begin{tabular}{cc}
\hline Presentase (\%) & Kriteria Kelayakan \\
\hline $90-100$ & Sangat layak, tidak perlu revisi \\
$75-89$ & Layak, tidak perlu revisi \\
$65-74$ & Cukup layak, perlu revisi \\
$55-64$ & Kurang layak, perlu revisi \\
$0-54$ & Tidak layak, revisi total \\
\hline
\end{tabular}

Apabila skor validasi yang diperoleh minimal 65, maka media atau bahan ajar yang dikembangkan tersebut sudah dapat dimanfaatkan sebagai media pembelajaran dalam kegiatan belajar di sekolah. Hasil analisis data berupa penilaina, tanggapan dari para ahli dipergunakan sebagai bahan untuk merevisi produk yang dikembangkan.

\section{HASIL DAN PEMBAHASAN}

Hasil dari penelitian pengembangan ini berupa buku panduan membaca cerita untuk membantu siswa terutama siswakelas IV dalam memahami isi cerita. Buku panduan membaca cerita ini dilengkapi dengan materi unsur intrinsik, panduan membaca untuk guru dan siswa, serta dilengkapi dengan soal pemahaman agar siswa mampu memahami cotoh cerita yang dipaparkan dengan baik. Pengembangan buku panduan ini dilakukan oleh peniliti dilihat dari hasil observasinya dibeberapa sekolah yaitu, UPT SDN Kauman 02, UPT SDN Kepanjenkidul 01, dan UPT SDN Kepanjenlor 03. Observasi ini menyimpulkan ada beberapa masalah yang diperoleh diantaranya, rendahnya kemampuan memahami cerita siswa dalam pembelajaran bahasa Indonesia. 
Hal itu disebabkan karena siswa kurang berkonsentrasi pada saat membaca, ramai sendiri ketika kegiatan membaca berlangsung, dan mempunyai minat yang rendah untuk membaca cerita. Permasalahan tersebut mengakibatkan kegiatan belajar mengajar tidak berjalan dengan baik dan siswa kesulitan dalam memahami materi ataupun cerita yang dibaca.

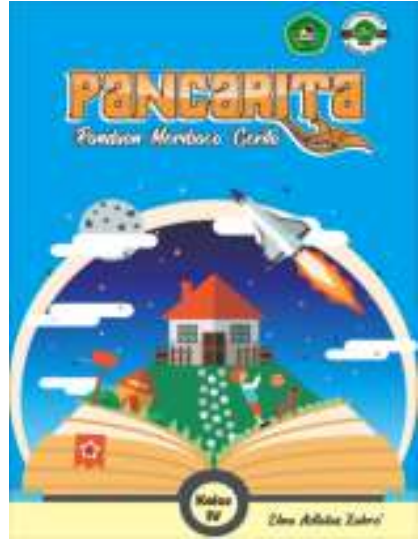

Gambar 3 Cover Depan

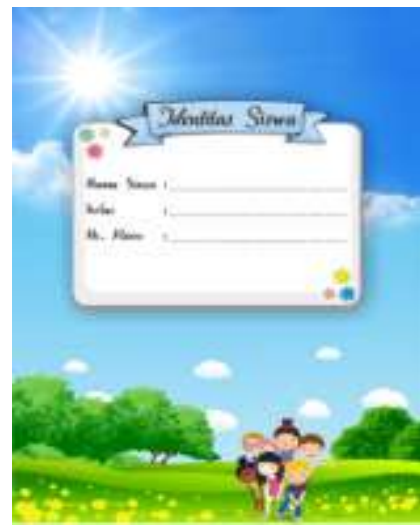

Gambar 6 Identitas Siswa

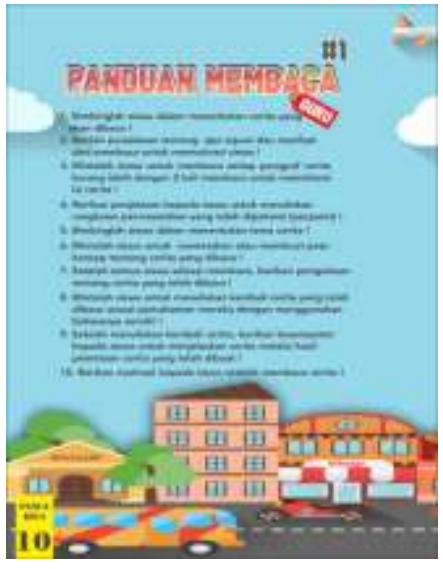

Gambar 9 Panduan Membaca Cerita Guru

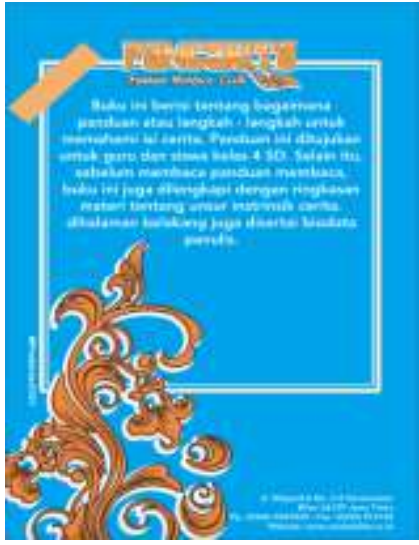

Gambar 4 CoverBelakang

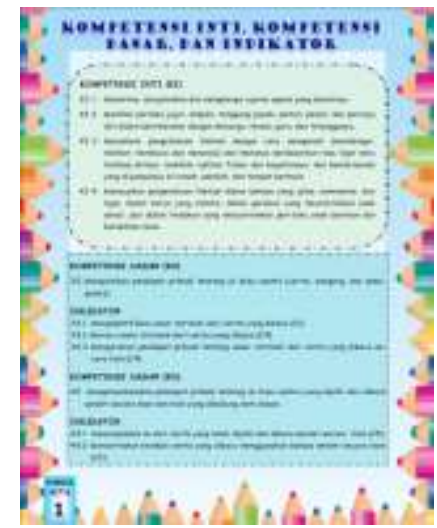

Gambar 7 KI,KD, dan Indikator (BG)

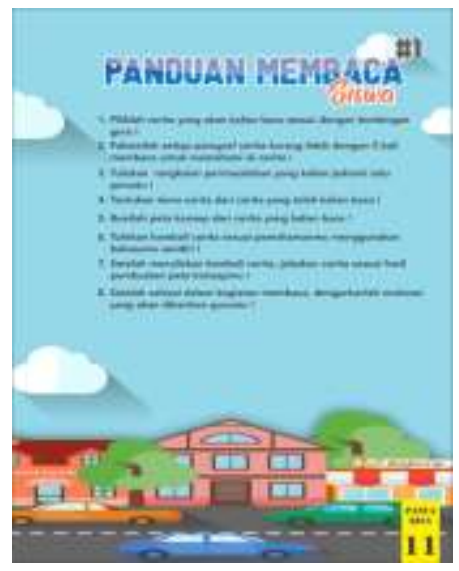

Gambar 10 Panduan Membaca Cerita Siswa

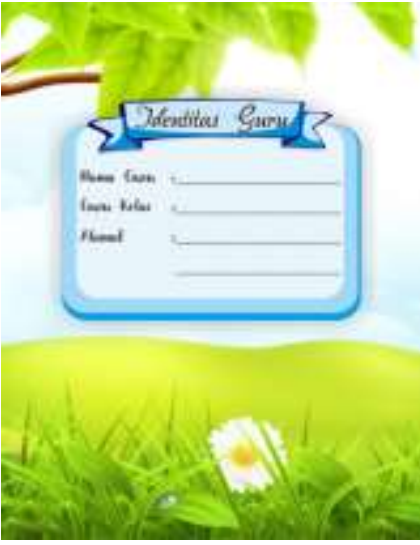

Gambar 5 Identitas Guru

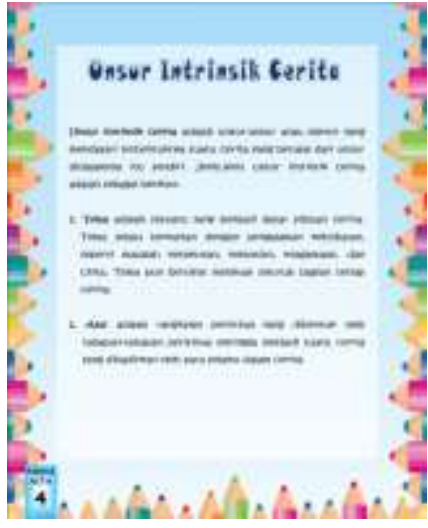

Gambar 8 Materi Unsur Intrinsik Cerita

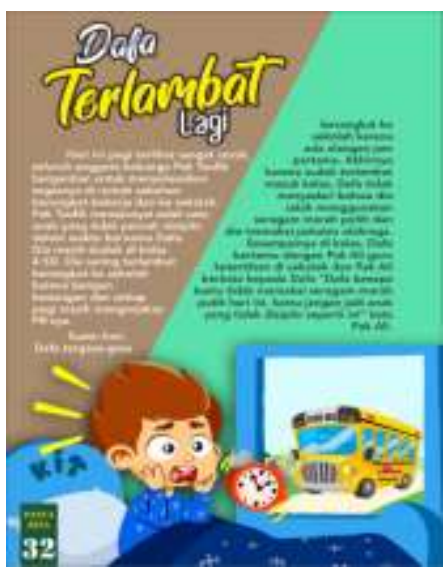

Gambar 11 Cerita Anak 


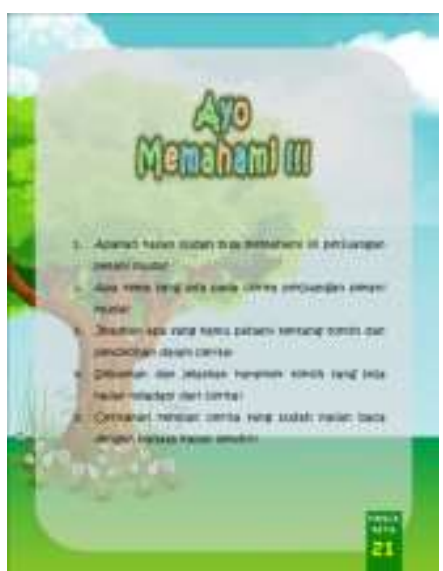

Gambar 12 Soal Pemahaman

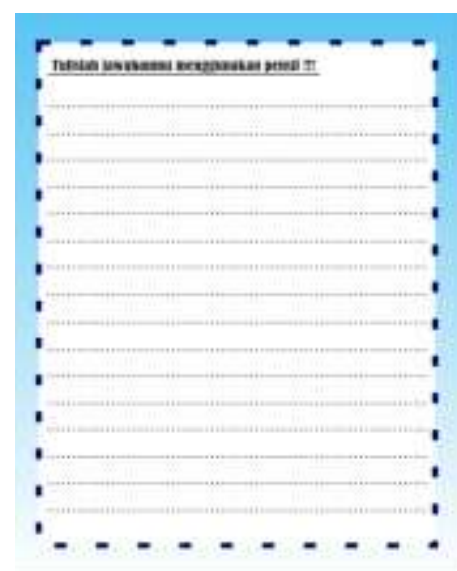

Gambar 13 Lembar Kerja Siswa

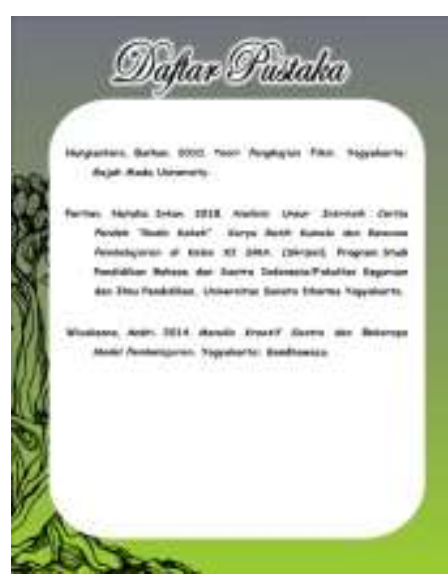

Gambar 14 Daftar Pustaka

Berdasarkan hasil analisis permasalahan tersebut, maka peneliti perlu mengembangkan bahan ajar yang menarik dengan penyajian materi dan cerita yang sesuai dengan siswa. Sehingga peneliti mengembangkan bahan ajar "Buku Panduan Membaca Cerita (PANCARITA) untuk Siswa Kelas IV" yang di desain dengan gambar karakter kartun dan penuh warna-warni menarik sesuai dengan usia siswa Sekolah Dasar. Hasil akhir dari pengembangan buku PANCARITA untuk guru dan siswa dapat dilihat pada Gambar 3 - Gambar 14

Saat melakukan pengembangan bahan ajar buku PANCARITA, peneliti akan melakukan tahapan validasi media kepada 9 validator yang terdiri dari 3 ahli materi, 3 ahli bahasa, dan 3 ahli media. Hasil validasi dari 9 validator seperti tampak pada Tabel 2, Gambar 15, Gambar 16, dan Gambar 17.

Tabel 2 Hasil Validasi Bahan Ajar

\begin{tabular}{ccccccc}
\hline Validator & $\mathbf{1}$ & $\mathbf{2}$ & $\mathbf{3}$ & Total & Kriteria skor & Persentase \\
\hline Ahli materi & 38 & 34 & 43 & 115 & 135 & $85 \%$ \\
Ahli bahasa & 32 & 37 & 36 & 105 & 120 & $88 \%$ \\
Ahli media & 82 & 83 & 78 & 243 & 270 & $90 \%$ \\
\hline
\end{tabular}

Ahli Materi

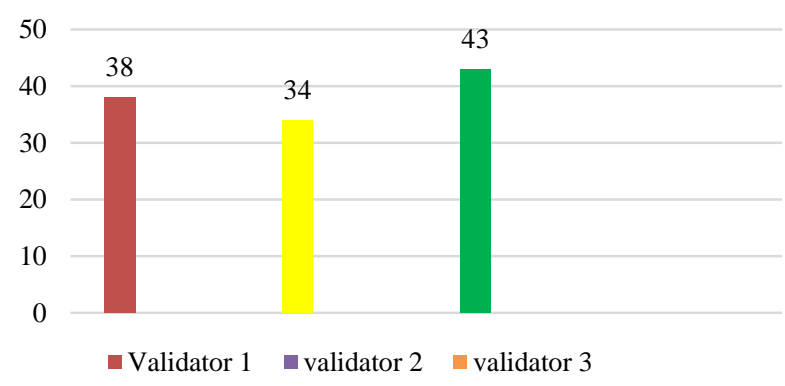

Gambar 15. Diagram Validasi Ahli Materi

Setelah melakukan tahap validasi, maka peneliti akan melakukan uji keterbacaan buku panduan membaca pada guru dan siswa. Uji keterbacaan dilakukan kepada 5 guru dan 10 siswa dengan hasil penilaian seperti pada Tabel 3, Gambar 18, dan Gambar 19.

Tabel 3 Hasil Uji Keterbacaan Bahan Ajar

\begin{tabular}{cccc}
\hline Uji keterbacaan & Total & Kriteria skor & Persentase \\
\hline Siswa & 95 & 100 & $95 \%$ \\
Guru & 464 & 500 & $93 \%$ \\
\hline
\end{tabular}


Rentang nilai yang digunakan dalam perhitungan penilaian validasi dan uji keterbacaan diperoleh dari rentang 90\%-100\% yang dikategorikan sangat layak, 75\% - 89\% dikategorikan layak, 65\% - 74\% dikategorikan cukup layak, 55\% - 64\% dikategorikan kurang layak, 0\% - 54\% dikategorikan tidak layak [6]. Sehingga nilai $85 \%$ oleh ahli materi termasuk kriteria layak digunakan. Nilai $88 \%$ oleh ahli bahasa termasuk kriteria layak digunakan. Nilai $90 \%$ oleh ahli media termasuk kriteria sangat layak digunakan. Hasil uji keterbacaan siswa memperoleh nilai 95\% termasuk kriteria sangat layak digunakan dan sesuai dengan siswa. Sedangkan hasil angket ketebacaan guru berjumlah 464 dari skor maksimal 500, diperoleh nilai persentase sebesar 93\% dari nilai persentase maksimal $100 \%$. Sehingga nilai $93 \%$ termasuk kriteria sangat layak digunakan dan sesuai dengan guru.

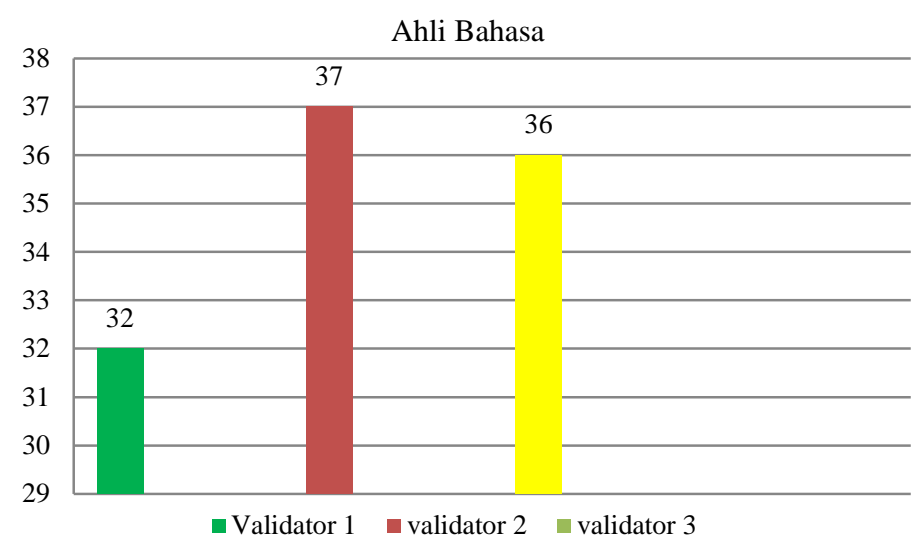

Gambar 16 Diagram Validasi Ahli Bahasa

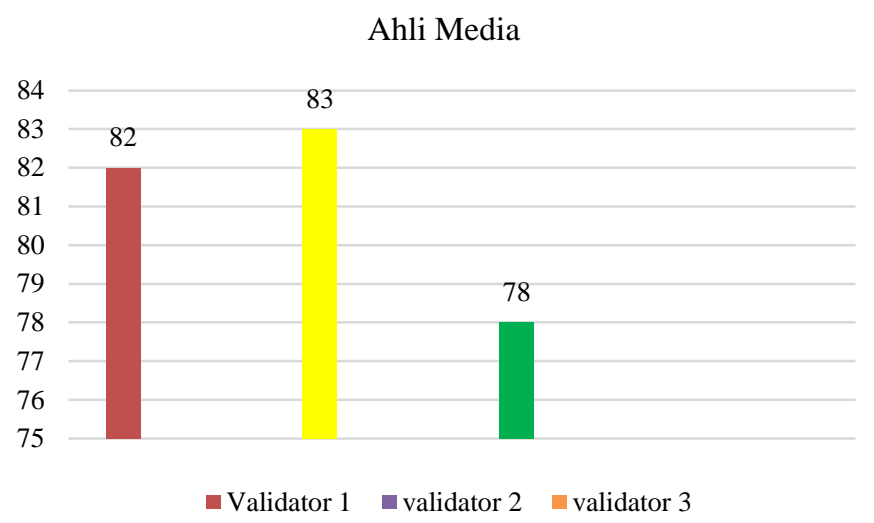

Gambar 17 Diagram Validasi Ahli Media

Bahan ajar yang sudah melalui tahap validasi dan uji keterbacaan tersebut sudah sesuai dengan pernyataan bahwa penggunaan media pembelajaran hendaknya bervariasi atau beranekaragam, karena setiap media memiliki kelebihan dan kekurangan. Kekurangan satu media dapat ditutupi oleh kelebihan media lain [7]. Selain itu, bahan ajar ini sudah dinyatakan layak dan baik untuk digunakan selama proses pembelajaran. Sesuai dengan pernyataan bahwa media yang baik adalah media yang penyajiannya jelas, menarik dan rapi, media yang sesuai dengan kebutuhan dan kemampuan siswa, media yang penggunaannya mudah untuk dibawa kemana-mana, dan media yang sesuai dengan tujuan pembelajaran [8].

Berdasarkan kriteria-kriteria kualitas media pembelajaran yang telah terpenuhi, maka bahan ajar buku PANCARITAdalam pembelajaran bahasa Indonesia kelas IV SD telah memenuhi kriteria valid dan layak. Dengan demikian, bahan ajar buku PANCARITAyang telah dikembangkan dapat digunakan sebagai bahan ajar untuk pembelajaran bahasa Indonesia di kelas IV SD materi cerita. 


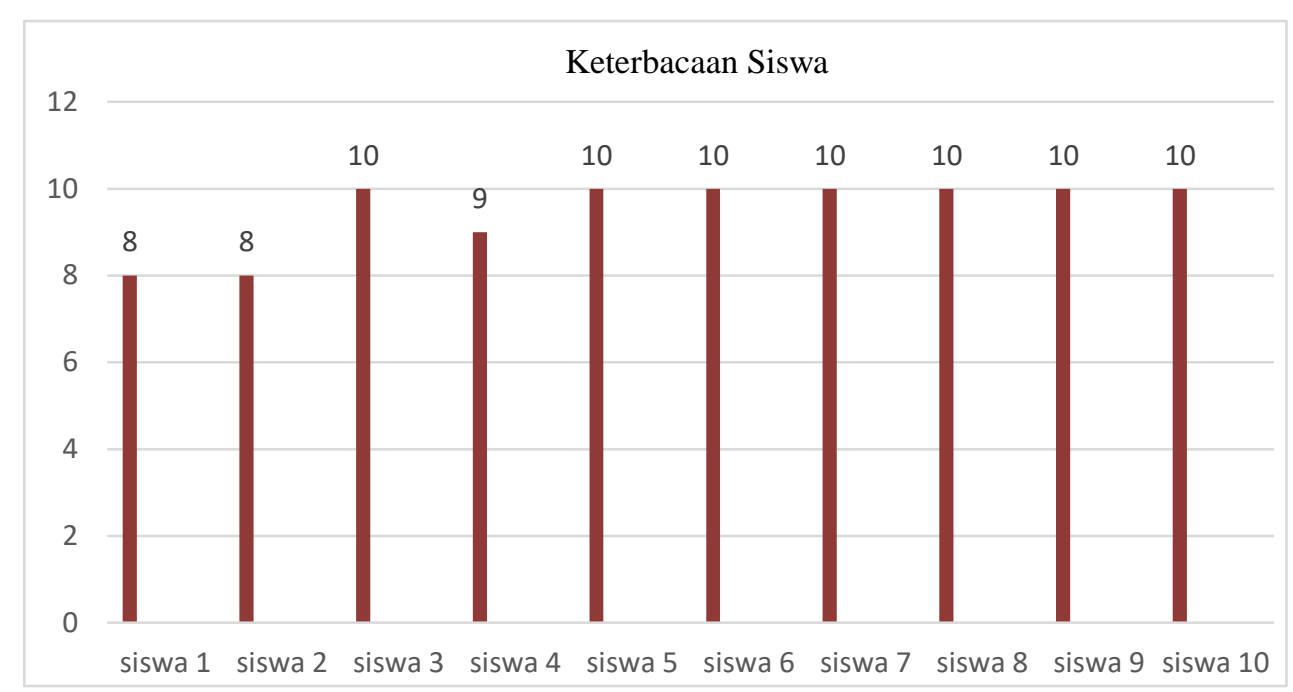

Gambar 18 Diagram Hasil Uji Keterbacaan Siswa

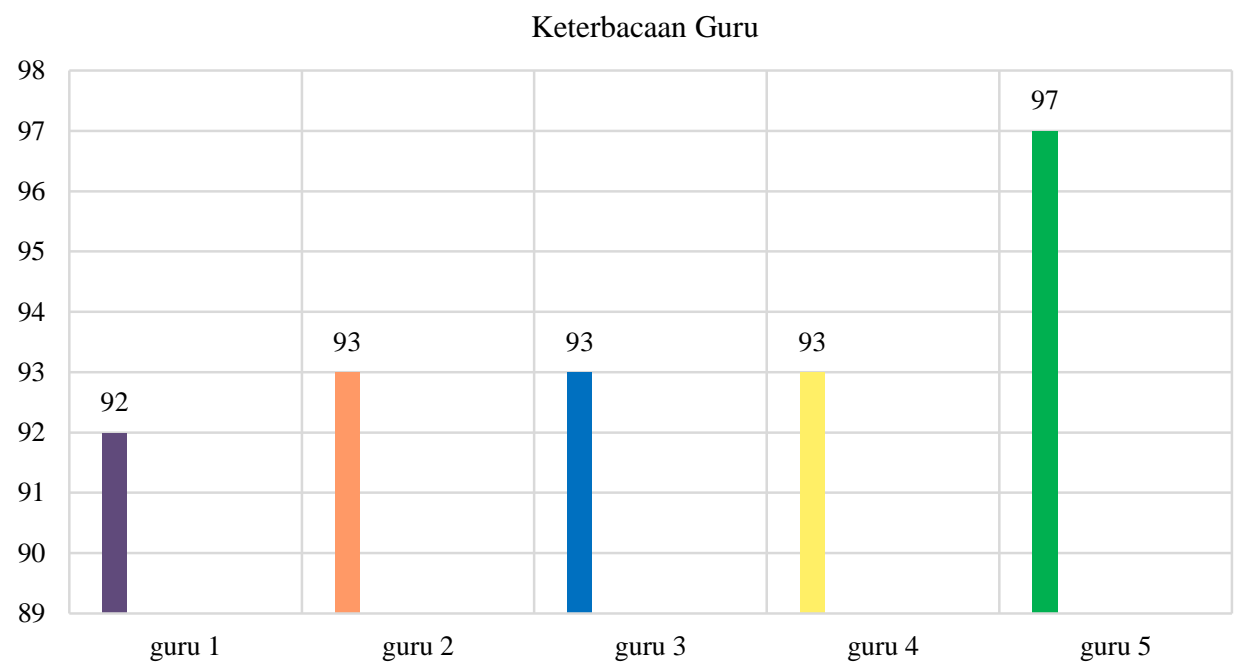

Gambar 19 Diagram Hasil Uji Keterbacaan Guru

\section{KESIMPULAN}

Penelitian pengembangan ini menghasilkan sebuah buku panduan membaca cerita untuk kelas IV SD.Tujuan pengembangan buku ini agar dapat meningkatkan kemampuan siswa dalam memahami isi cerita dan mempermudah guru dalammembimbing siswa pada saat kegiatan membaca cerita. Buku ini dapa digunakan guru sebagai bahan ajar tambahan untuk menganalisis konsentrasi siswa pada saat kegiatan membaca, menganalisis pemahaman siswa terhadap kosa kata baru, dan menganalisis pemahaman siswa terhadap cerita melalui kegiatan menceritakan kembali cerita.

Berdasarkan uji coba yang telah dilakukan, dapat disimpulkan bahwa, hasil validasi buku panduan oleh ahli materi diperoleh persentase $85 \%$ dinilai layak, ahli media dengan persentase $90 \%$ dinilai sangat layak dan ahli bahasa dengan persentase $88 \%$ dinilai layak. Sedangkan hasil uji keterbacaan yang didapat dari siswa diperoleh persentase $95 \%$ dinilai sangat layak dan hasil uji keterbacaan guru dengan persentase $93 \%$ dinilai sangat layak. 


\section{DAFTAR PUSTAKA}

[1] Prastowo, Andi. Panduan Kreatif Membuat Bahan Ajar Inovatif. Yogyakarta: DIVA Press,2012

[2] Darmiyati, Zuchdi dan Budiasih. Pendidikan Bahasa dan Sastra Indonesia di Kelas Rendah. Yogyakarta: PAS, 2001

[3] Machmuda, Ayu Kurnia. Pengembangan Bahan Ajar Membaca Cerita Anak Berbasis Cerita Rakyat Jawa Timur Untuk Siswa Kelas V MI Nurul Huda Malang. (Skripsi), Pendidikan Guru Madrasah Ibtidaiyah/Fakultas Ilmu Tarbiyah dan Keguruan, Universitas Islam Negeri Maulana Malik Ibrahim, Malang, 2013.

[4] Kristianto, Benedictus Aditya. Pengembangan Buku Cerita Anak Berbasis Pendidikan Lingkungan Hidup Untuk Pembelajaran Membaca Kelas Bawah. (Skripsi), Program Studi Guru Sekolah Dasar/Fakultas Keguruan dan Ilmu Pendidikan, Universitas Sanata Dharma, Yogyakarta, 2017.

[5] Sugiyono. Metode Penelitian dan Pengembangan Pendekatan Kualitatif, Kuantitatif, danR\&D. Bandung: Alfabeta, 2010.

[6] Nisa', Rofiatun. Pengembangan Media Monopoli 3 Dimensi Untuk Meningkatkan Hasil Belajar Subtema Makananku Sehat dan Bergizi Kelas 4 SDI. (Skripsi), Pendidikan Guru Madrasah Ibtidaiyah/Fakultas Ilmu Tarbiyah dan Keguruan, Universitas Islam Negeri Maulana Malik Ibrahim, Malang, 2015.

[7] Sumiati, Asra. Metode Pembelajaran. Bandung: CV Wacana Prima, 2007.

[8] Asyhar, Rayandra. Kreatif Mengembangkan Media Pembelajaran. Jakarta: Referensi Jakarta, 2012. 